\title{
Erratum to: Understanding the role of contrasting urban contexts in healthy aging: an international cohort study using wearable sensor devices (the CURHA study protocol)
}

\author{
Yan Kestens ${ }^{1,2^{*}}$, Basile Chaix ${ }^{3}$, Philippe Gerber ${ }^{4}$, Michel Desprès ${ }^{5}$, Lise Gauvin ${ }^{1,2}$, Olivier Klein ${ }^{4}$, Sylvain Klein ${ }^{4}$, \\ Bernhard Köppen ${ }^{4}$, Sébastien Lord ${ }^{5}$, Alexandre Naud ${ }^{1,2}$, Marion Patte ${ }^{4,6}$, Hélène Payette ${ }^{7}$, Lucie Richard ${ }^{8}$, \\ Pierre Rondier ${ }^{1}$, Martine Shareck ${ }^{9}$, Cédric Sueur ${ }^{10}$, Benoit Thierry ${ }^{1}$, Julie Vallée ${ }^{6}$ and Rania Wasfi ${ }^{1,2}$
}

\section{Erratum}

After publication of this work [1], we noted that we inadvertently failed to include the complete list of all coauthors: co-author Marion Patte was missed. In addition, the affiliations for Cédric Sueur and Julie Vallée were mistakably reversed. The full list of authors, corrected author affiliations and the updated Authors Contributions section are reported here, and have also been corrected in the original article. We apologize for any inconvenience this oversight may have caused.

\section{Authors' contributions}

$\mathrm{YK}, \mathrm{BC}$ and $\mathrm{PG}$ are the principal investigators of the CURHA study. Together with LG, SL, HP, MP, LR, OK, $\mathrm{CS}, \mathrm{BT}, \mathrm{AN}, \mathrm{JV}, \mathrm{RW}$ they conceived and designed the study. BK, MS and PR have/are coordinating the data collection campaigns in Canada and Luxembourg. All authors revised and approved the submitted manuscript.

\section{Author details}

'Montreal University Research Center (CRCHUM), 850, rue St-Denis, Montréal, QC H2X 0A9, Canada. 'École de Santé Publique de I'Université de Montréal (ESPUM), 7101, rue du Parc, Montréal, QC H3N 1X9, Canada. ${ }^{3}$ Inserm, UMR-S 1136, Pierre Louis Institute of Epidemiology and Public Health, Faculté de médecine Saint-Antoine, 27 rue Chaligny, cedex 12, Paris 75571, France. ${ }^{4}$ Luxembourg Institute of Socio-Economic Research, 11, Porte des Sciences, Esch-sur-Alzette L-4366, Luxembourg. ${ }^{5}$ École d'urbanisme et d'architecture de paysage, Université de Montréal, 2940, chemin de la Côte-Sainte-Catherine, Montréal, QC H3C 3J7, Canada. 'UMR Géographie-Cités, 13 rue du Four, Paris

*Correspondence: yan.kestens@umontreal.ca

'Montreal University Research Center (CRCHUM), 850, rue St-Denis, Montréal, QC H2X OA9, Canada

2École de Santé Publique de l'Université de Montréal (ESPUM), 7101, rue du Parc, Montréal, QC H3N 1X9, Canada
75006, France. ${ }^{7}$ Canada Research Center on Aging, CIUSSS de l'Estrie-CHUS, Faculty of Medicine \& Health Sciences, University of Sherbrooke, Sherbrooke, QC, Canada. ${ }^{8}$ Faculty of Nursing, Université de Montréal, Montreal, QC H3C 3J7, Canada. 'London School of Hygiene and Tropical Medicine, London, UK. ${ }^{10}$ Département d'Ecologie, Physiologie et Ethologie; Institut Pluridisciplinaire Hubert Curien, 23, rue Becquerel, Strasbourg 67087, France.

Received: 13 June 2016 Accepted: 13 June 2016

Published online: 05 July 2016

\section{Reference}

1. Kestens $Y$, Chaix B, Gerber P, Desprès $M$, Gauvin $L$, Klein $O$, et al. Understanding the role of contrasting urban contexts in healthy aging: an international cohort study using wearable sensor devices (the CURHA study protocol). BMC Geriatrics. 2016;16:96. doi:10.1186/s12877-016-0273-7.
Submit your next manuscript to BioMed Central and we will help you at every step:

- We accept pre-submission inquiries

- Our selector tool helps you to find the most relevant journal

- We provide round the clock customer support

- Convenient online submission

- Thorough peer review

- Inclusion in PubMed and all major indexing services

- Maximum visibility for your research

Submit your manuscript at www.biomedcentral.com/submit
C Biomed Central (c) 2016 The Author(s). Open Access This article is distributed under the terms of the Creative Commons Attribution 4.0 International License (http://creativecommons.org/licenses/by/4.0/), which permits unrestricted use, distribution, and reproduction in any medium, provided you give appropriate credit to the original author(s) and the source, provide a link to the Creative Commons license, and indicate if changes were made. The Creative Commons Public Domain Dedication waiver (http://creativecommons.org/publicdomain/zero/1.0/) applies to the data made available in this article, unless otherwise stated. 